\title{
Anton Salmin
}

\author{
Peter the Great Museum of Anthropology and Ethnography (Kunstkamera) \\ Russian Academy of Sciences, Saint Petersburg, Russia \\ antsalmin@mail.ru
}

\section{The Beer Tradition of the Chuvash}

\begin{abstract}
The Chuvash are the indigenous population of the Chuvash Republic, located on the Middle Volga with its capital at Cheboksary. The Chuvash brewed beer using flour, malt and hops. Barley was considered the most suitable grain. Among the Chuvash beer was a ritual beverage. They never drank it without specific cause. After the harvest had been gathered, beer was made with the fresh grain. Kinfolk would gather for the occasion. The very fact of beer-brewing speaks of this people's agricultural way of life. Wooden tubs were used for brewing large quantities of beer, while smaller amounts were made in pots. This drink is considered sacred among the Chuvash. It is dedicated to deities of high rank and also to the spirit of ancestors. Valued guests are welcomed and seen off with it.
\end{abstract}

Key words: beer, traditions, Chuvash, ritual food, ritual drink, barley

\section{Introduction}

According to Chuvash traditional conceptions (Salmin 2019), the symbolic feeding of deities and spirits is the most important concern in the life of an upstanding person. Periodically, and in the intervals between these times in exceptional circumstances, he or she should take ěśme-síme (literally "drink-food") to some sacred place. Offerings in the very broadest sense of the word are a component part of the religious system (Arutiunov 1989, 137). Ceasing to make offerings is tantamount to a cessation of the cycle of life. Therefore, a study of the system of oblation as the highest element in the religious consciousness of many peoples (Malik 1980, 83) is a relevant part of religious studies.

Works on the classification and interpretation of oblations as systems do exist (Jennings 2005, 275-303). The Chuvash material is no exception. For example, N.V. Nikol'skii assessed the offering as an expression of a person's attitude to the deities (Nikol'skii 1919, 93f). He considered domesticated animals and birds, vegetables, comestibles and beverages as suitable offerings. He also included dough or clay images taking the place of animals. Naturally, the range is even broader. For example, providing a guest with refreshment and all manner of donations is also an act of oblation. Present-day sponsorship is similarly a sacrificial gift. 


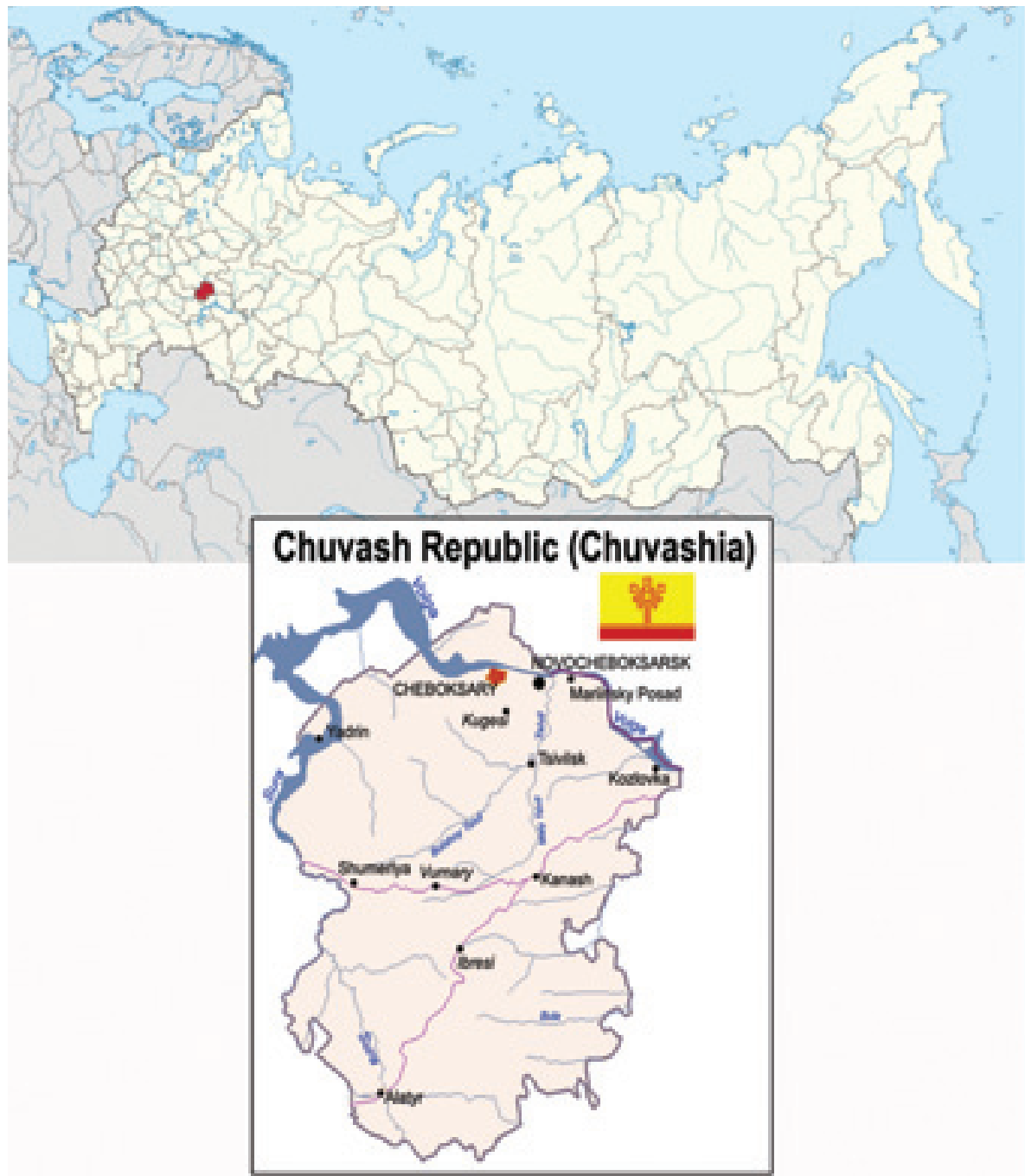

1) A map of Russia showing the location of the Chuvash Republic.

It is known a priori that oblation among the Chuvash takes the form of a complex system. In world religions however, the rules about making sacrifices and offerings have been elevated into a more complex canonized system than in traditional folk rites and beliefs.

\section{Materials and Methods}

Before writing this paper, the author studied hundreds of books and periodicals, and spent many years among the members of this culture. He is himself 
a native Chuvash, a bearer of the culture in question, who has made several special expeditions to districts of the Chuvash Republic, as well as to Orenburg, Samara, Saratov and Ulyanovsk regions (oblasti). He has also de visu analysed the technology of beer-making, and studied the contextual significance of beer consumption in ritual and everyday situations.

\section{Results and Discussion}

In the Chuvash language beer is săra (also kěrčeme and hurśă). Mentions of this beverage can be found in Egyptian and Western Asian texts of the 4 th -3 rd centuries BC. There are, however, grounds for speaking about the consumption of beer in even earlier times. For example, the Romans called it a drink of the Scythians and Germanic peoples and drank it as an alternative to wine. Words akin to the Chuvash săra (Persian shire, Iranian hura, Sanskrit sura - "juice, sweet syrup; intoxicating beverage") (Egorov 1964, 183) argue in favour of an Eastern (more precisely, Indo-Iranian) origin for beer. The Udmurt word sura and Komi sur should also be considered borrowings from Iranian.

Beer-brewing among the Chuvash was each time connected with a specific ritual. All the brew would usually be used up during the ceremony to which it was dedicated. Judging by the written materials, beer would be brewed shortly before the event. That is why, among other things, the Chuvash have a saying: "For weddings, evidently, beer must be made" (Ashmarin 1936, 271). For a marriage, for example, beer would be prepared three days before the ceremony. In autumn or winter, after the completion of all the work in the fields and the drying of the crop, and also after snow fell, beer was brewed from freshly harvested grain and the ritual called cü̈kleme was celebrated. While the drink was, as a rule, brewed three days before consumption, the necessary utensils were prepared earlier - five or six days ahead. They consisted of 480-litre barrels to hold the finished beverage, tubs for fermentation, a beer trough, beer pots, ladles and so on. These items

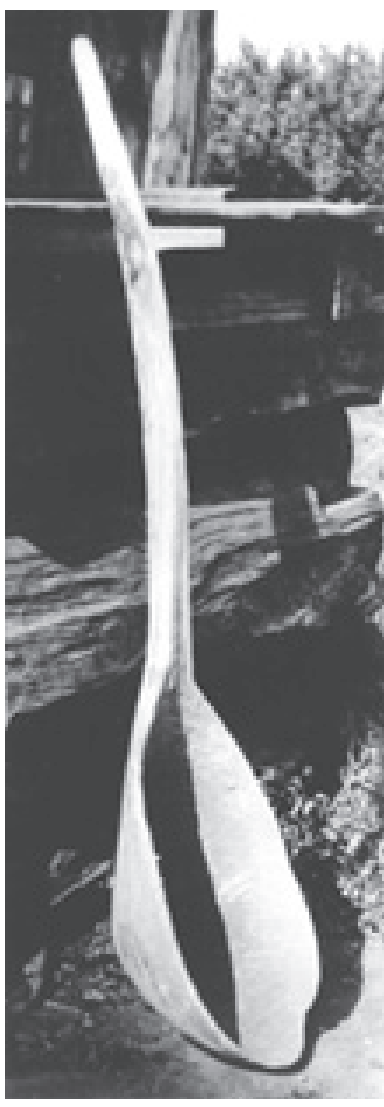

2) A ladle used for stirring and pouring when making beer in large quantities (Archive of the Chuvash

State Institute of the Humanities. Section VIII. Vol. 383. Inv. No 2981a). 
were necessary so that the correct procedure for making and storing the drink could be followed.

The main ingredients of beer are flour, malt and hops. The Chuvash considered barley the most suitable grain for the purpose (Ashmarin 1936, 272). Barley and also maize, rice and millet have been used by many peoples at different times. A drink which has grain as its chief component could only be produced by settled tillers of the soil. Researchers confirm this (Arutiunov, Vainkhol'd $1989,85)$. Besides, the process itself requires sedentary conditions. In a macro-ritual situation, when each participant wants to make their contribution to the sacral event, they bring foodstuffs and firewood to the agreed site. In the "Folk beer" ritual, several old people agree to bring malt and flour, and after all the participants have brought their share of firewood, the preparations begin. In the viśśšs (post-funeral feast), shavings and chippings left over from the making of the coffin are used instead of the usual firewood. The other ingredients are placed in the tub and then the yeast is added. A watch is kept on the fermenting mixture until the following day, to prevent it spilling over. In the case of rituals involving the whole village, after the filtering of the wort the participants gather once again and share the stillage amongst themselves (as animal feed). A small portion of the fermented wort and the freshly strained beer is poured out to honour the spirits of the ancestors. Then the beer is tasted by experts in the brewing process. Sometimes a relative or neighbour is invited for this purpose. The beer is poured from the tub into the barrels (Ashmarin 1936, 272f).

Besides the traditional practice of brewing in a tub, beer was also made in pots if only a small quantity was required. There was also what was known as "field beer", which was brewed in a large quantity for rituals involving a whole village or more than one village. These practices have fallen into disuse and are in the main forgotten. We can find indications in terms and toponyms, such as "the bend in the gully where they made beer".

The fermented beer is strained through a bast sieve into another tub and then poured into barrels. The freshly strained beer is particularly enjoyable because at that moment it is at its most frothy and, so they say, produces a play of different colours (Ashmarin 1941, 302).

Beer that is kept for too long becomes covered in mould (fungal growth) and has a bitter taste. Such beer is unpleasant to drink and is considered spoilt.

That is why songs sometimes poke fun at heads of households who lay in large stocks of beer:

"We came to drink beer

Covered with mould" (Ashmarin 1950, 335).

If necessary, the required quantity of beer is prepared in several brewings. The sources mention the figure three: 
In the speech of a "master of ceremonies" at a wedding, for example:

"From six sacks of barley, They brewed beer in three goes."

Vessels from which beer is served at the table include pails, jugs and casks. Besides the main vessels, seven or eight scoops full of beer would be placed on the table

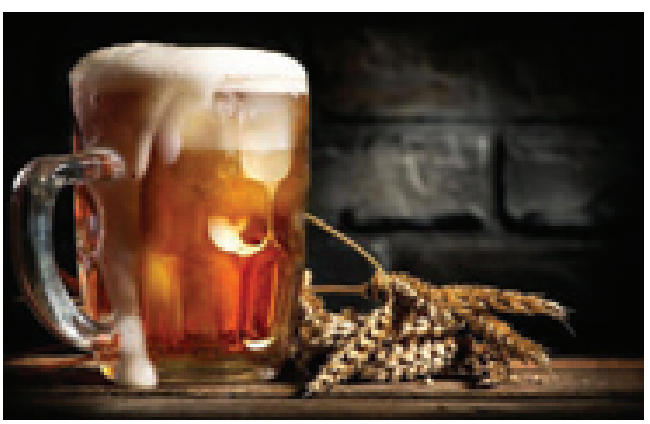

3) Beer in a mug. for pouring the drink into mugs. After the guests had been seated in accordance with their status and gender, they were brought personal mugs. Sometimes all the mugs on the table were filled and then handed out; sometimes, though, they were filled one at a time and brought to each guest. Those serving kept strict watch to ensure that the guests drained their mugs completely. If they failed to do so, the servers would not take the vessel back. All the mugs were collected only when the last participant had shown its empty bottom to the server, the host or a neighbour. After gathering all the mugs together on the table, they took a break during which they did other things (talked, ate, danced and so on). It was considered quite normal for a host to have 40 mugs on the table. For clan rituals, which lasted at least 24 hours, it was also considered ideally desirable to serve beer 40 times.

In the light of this, it should be noted that the criticism of Chuvash rituals for supposedly using a single mug (or scoop) with the associated risk of passing on infections is unjustified. If such things did occur, it was not the traditional practice, but some modified version. Beer was carried from the home to some other place, such as the cemetery, in jugs.

The bulk of texts make no mention of intoxication from the drinking of ritual beer. One gets the well-founded impression that beer was a drink for mass consumption from time immemorial. The "People's beer" ritual, for example, lasts a whole day. The main activity is the drinking of specially brewed beer, with the entire village participating, including children. The effects of the beer do nonetheless manifest themselves, if only in the fact that women coming back from a party during Śăvarni (an equivalent of Shrovetide) complain of headaches. Compared to vodka, after drinking beer a person does not feel hungry, does not have the desire to drink more and does not get heavily intoxicated. Nevertheless, beer does count as an intoxicating beverage. Sura in Ancient India, for example, was no exception. Remarks about some degree of intoxication caused by beer at Chuvash weddings are justified. That is why beer should be classified as a drink appropriate for consumption by people only above a certain age. Regard- 
ing kerrčeme, it should be noted that this is clearly an intoxicant. On the other hand, the Chuvash also produce makăsma, a "beer" made without hops or yeast, which is non-intoxicating.

The high sacral status of beer is evidenced by the attitude shown towards it in rituals. Irrespective of the type of rite, freshly-made beer is drunk first in honour of the deity Tură. Other addressees are the spirits of ancestors, and old people (that is the case at a wedding and in the clan rites of jupa, munkun and kér sari). The fact that elderly people oversee the preparation and distribution of beer should evidently also be viewed in this same light. People are welcomed and seen off with beer. It is used to bless a bride and groom: at the wedding the parents and the couple themselves each drink half of one large scoop of beer. Later in the year, the grateful newly-weds go to the home of the bride's parents taking beer with them as an expensive and respectful gift.

Beer also serves as the main offering gift since in the majority of cases when listing ritual refreshments informants name the beverage first, while referring to all other comestibles by the general word ěśme-śime ("drink-food"). In the clan ritual cükleme, among others, guests are each given a mug of beer. In their other hand they receive bread made with grain from the last harvest and salt. As we see, in this version beer and bread-and-salt (as a symbol of welcome) hold equal status. In another variant of cükleme each person stands up to pray with their own mug of beer. In both cases, the drink, home-made from the latest grain, is a vital accompaniment to ritually addressing the deities of the highest order.

Beer may serve as an occasion to gather together and chat. For example, in the "People's beer" ritual old men get together, drink beer and talk. As for young people, they rarely drank the beverage, only at social gatherings for instance. Unmarried girls drank only home-made beer brewed the right way (with low alcohol). It was also considered normal for some to dislike the drink. For instance, after completing the main requirements, some of the participants in the "People's beer" ritual who disliked the beverage, went back home, while others remained, alternating entertainment in the form of games with the consumption of beer.

Beer is among the main preparations for an act of prayer and subsequent oblation, especially in family-clan rituals. Of 389 examples of the use of ritual beer selected for analysis, 45 consist of the jupa rite, 35 are weddings, 33 čükleme and so on. In these, beer is present throughout the ritual, from beginning to end. There is also a separate ritual for the offering of beer. Each stage of the ritual calls for a new portion of beer (a fresh barrel, another pail, and so on). And so plenty of beer was brewed. For the clan ritual munkun, for example, they prepared particularly tasty food, brewed three or four barrels of beer and brought in wine. During the clan feast éske rich people would brew up to 50 barrels of beer, poor people made do with 20. Jupa called for 30-40 barrels. For prayer people stand up holding a mug of beer. Then they pour a little out into a special vessel. That is the case with munkun, for example, or when seeing someone off 
who is going to join the army. The beer thus collected and scraps of the food are poured out behind the house. It is believed that people in the next world will use that beer and the other comestibles. If they do not receive their share, they may remind the living of their existence. That is why on days of commemoration of the dead (jupa, simék) part of the beer is poured onto the grave. The portion being allotted should first be poured into the palm and then the libation is made from the hand.

Wine, kasha (boiled cereal) and pancakes are considered compatible with ritual beer.

Among the acceptable substitutes for beer, water and sour milk are mentioned. The fact of water serving as a replacement is illustrated by this example. During the ritual of the autumn remembrance of the dead, as the share for the deceased without kin people take out to the gates three small pancakes, a scoop of beer and water, and also a bucket of water for rinsing dishes. When honouring long-dead relatives a libation of beer is not customary, but rather one has to leave the ingredients needed to make it: malt, hops, water and flour.

Beer plays an important part in Chuvash rituals and this is reflected in the names of a whole number of rites. These include "Autumn beer", "Maiden's beer" and "People's Beer". A curious and, evidently, archaic detail is suggested by the expression tună hurśă, which literally means "made steel". Nikolai Ashmarin's fundamental dictionary of the Chuvash language defines the phrase as "victuals; a meal". However, the present author happened to hear and record the word hurśă in the more specific meaning of "beer" on an expedition in 1990. While citing the text of the prayer accompanied with beer in munkun and during păt-jusman jĕrki, the informant used the phrase piśně jaškapa, tună hurśăpa - literally "boiled soup, made steel" (in the instrumental case) and on seeing my questioning look explained that tună hurśă is "beer". I recorded a similar turn of phrase - tună săra, "prepared beer" - during that same expedition. It still remains unclear why the expression includes specifically the word hurśă "steel". I can suggest the following version: it is a known practice for beer brought to the table in a pail to be warmed up by plunging a red-hot poker into it. The idea that the meaning of tună hurśă in the examples cited by Ashmarin was not actually the broad one of "food; a meal" is borne out by the texts themselves. In the prayer that accompanies starting on a new barrel people say "Give a full table of hurśă ", most probably referring to beer. Or "Let hurśă be lacking; instead there is bread" - here a broad meaning cannot be intended, as bread is a basic foodstuff.

A similar context is present in the following example:

"Boiled soup for us, it appears,

Made hurśă for you, it appears."

The term hurśă is also used in the meaning of "a deity", which considerably expands the semantics of the word and does not contradict the view expressed here. 
In the verbal text, of course, the addressees are informed about the type of offering being made to them. In the case of rituals involving beer the speeches of the person officiating stand out which specify the conditions that should be observed when drinking the proffered mug. For example, it is not permissible to laugh, to wipe one's lips, to raise the mug too high. An offender is punished by having to drink five mugs seven times in succession in the presence of the company.

The above makes it possible to conclude that beer has an exalted status. Its significance acquires a character that is not only ritual but more general to the culture. In conclusion, let me cite one example. During the great spring solstice festival of munkun, the eldest (usually male) member of the family goes out to the gate in the early morning to summon the spirits of ancestors. He takes with him bread, beer and a few slivers of wood for making a symbolic bonfire. It is a well-known fact that an equal's sign can often be placed between sacral concepts. In this case, "deity", "bread", "beer" and "fire" are such concepts.

Conclusion

In general, vodka, beer and mead stand out among libationary offerings. Beer will be brewed at a particular time and in a particular quantity for use in a specific ritual. Irrespective of the type of ritual, fresh beer was first drunk in honour of Tură. Other addressees are the spirits of ancestors and old people.

It would not be true to say that this ethnic group suffered great losses from making offerings, since almost everything was consumed by the participants in a ritual, although oblation was also accompanied by major expenses. If we view the situation from a rational point of view, then it must be said that they set aside as offerings small pieces, bones or feathers, which were left or burnt. In terms of mentality, the society gained spirituality and became more united. Participants in a collective meal became practically relatives for the rest of their lives. For that reason, it is possible to state that the participants in major offerings did not lose anything, but on the contrary gained significantly.

The same can be said of the genres of Učuk (collective village prayers to mark the end of the sowing season) and jupa, as the most demanding in terms of offerings. The offering rituals are marked by detailed regulation, since the deities and spirits were believed to respond benevolently without fail, providing the offerings were made in compliance with all the rules. On the whole, an analysis of the types, characteristics and semantic aspects of the offerings makes it possible to conclude that the economy of the Chuvash people was characterized by a settled way of life based on agriculture and animal husbandry. Although this particular work does not have an ethnogenetic characterization as a goal, 
impartial facts should be taken into account. For example, the present research has made it possible to draw conclusions about analogies, primarily with the Mari, Udmurts and Russians.

\section{References}

Arutiunov, S.A. 1989. Narody i kul'tury: razvitie i vzaimodeistvie [Peoples and Cultures: Development and Interaction] Moscow (in Russian).

Arutiunov S.A., Vainkhol'd R. 1989. Napitki [Drinks] In Svod etnograficheskikh poniatii i terminov [A Compendium of Ethnographical Concepts and Terms]. Part 3. Moscow (in Russian).

Ashmarin, N.I. 1936. Slovar' chuvashskogo iazyka [A Dictionary of the Chuvash Language]. Part XI. Cheboksary (in Chuvash).

Ashmarin, N.I. 1941. Slovar' chuvashskogo iazyka [A Dictionary of the Chuvash Language]. Part XVI. Cheboksary (in Chuvash).

Ashmarin, N.I. 1950. Slovar' chuvashskogo iazyka [A Dictionary of the Chuvash Language]. Part XVII. Cheboksary (in Chuvash).

Egorov, V.G. 1964. Etimologicheskii slovar' chuvashskogo iazyka [An Etymological Dictionary of the Chuvash Language] Cheboksary (in Chuvash).

Jennings, Justin; Antrobus, Kathleen L.; Atencio, Sam J.; Glavich, Erin; Johnson, Rebecca; Loffler, German; and Luu, Christine. 2005. Drinking Beer in a Blissful Mood Alcohol Production, Operational Chains, and Feasting in the Ancient World, Current Anthropology 46-2: 275-303.

Malik, Madhusudan. 1980. Introduction to Parsee religion, Customs and Ceremonies. Santiniketan.

Nikol'skii, N.V. 1919. Kratkii konspekt po etnografii Chuvash [A Brief Outline of the Ethnography of the Chuvash] Kazan (in Russian).

Salmin A.K. 2019. Saviry, bulgary i tiurko-mongoly v istorii chuvashei [Saviris, Bulgars and Turkic-Mongols in the history of Chuvash]. - Saint Petersburg: Nestor-Istoriia. (in Russian).

Антон Салмин

Музеј антропологије и етнографије „Петар Велики“ (Кунсткамера), Руска академија наука, Санкт Петербург, Русија

\section{Пивске традиције Чувашаิ}

Чуваши су староседелачко становништво Чувашке Републике која се налази на Средњој Болги, док је главни град Чебоксари. Пиво је код Чуваша обредно пиће које се није пило без разлога. За пивовару су Чуваши користили брашно, слад и хмељ. Најпогоднијим зрном су сматрали јечам. Након жетве се од новог зрна справљало пиво, којом приликом се скупља- 
ла родбина. Само постојање пивоваре говори о пољопривредном начину живота тог народа. Пиво справљено са хмељом изазива опијеност, док степен опијености зависи од трајања врења. Ако је припремљено без хмеља, то је безалкохолно пиће. За припрему велике количине пива користиле су се бачве, а за малу количину лонци. Ово пиће се сматра код Чуваша сакралним. Посвећује се божанствима високог ранга те духовима предака. Њиме се дочекују и прате драги гости.

Кључне речи: пиво, традиције, Чуваши, обредно јело, јечам

\section{Les traditions des Tchouvaches liées à la bière}

Les Tchouvaches sont une population autochtone de la République de Tchouvachie. La capitale en est Tcheboksary, et le pays se trouve sur le cours moyen de la Volga. La bière est chez les Tchouvaches une boisson rituelle que l'on ne consommait pas sans raison particulière. Toute la famille se réunissait lors de sa préparation. L'orge était considéré comme le grain le plus convenable, et, après la moisson, avec du nouveau grain on faisait de la bière. Pour la production de la bière les Tchouvaches utilisaient la farine, le malt et le houblon. L'existence de la brasserie témoigne du mode de vie agricole de ce peuple. La bière faite avec du houblon provoquait l'ébriété dont le degré dépendait de la durée de la fermentation. Lorsqu'elle était préparée sans houblon, c'était alors une boisson sans alcool. Pour la préparation d'une grande quantité de bière on utilisait des tonneaux, alors que pour de petites quantités on se servait des pots. Cette boisson est considérée comme sacrale chez les Tchouvaches. Elle est consacrée à des divinités de haut rang puis à des esprits des ancêtres. Elle sert aussi à saluer l'arrivée et le départ des invités chers.

Mots clés: bière, traditions, Tchouvaches, plat rituel, orge

Primljeno / Received: 09.11.2019

Prihvaćeno / Accepted: 09.02.2020. 